\title{
Determination of the Level of Mercury Toxicity of Fish in Rivers Draining Gold Panning Sites in the Territory of Fizi, Eastern Democratic Republic of Congo
}

\author{
Nsambu Mukondwa Pascal ${ }^{1,2,3, ~ *}$, Musibono Eyul'Anki Dieudonné ${ }^{1}$, Mputu Kanyinda Jean-Noël ${ }^{1}$ \\ ${ }^{1}$ Department of Environmental Sciences, Faculty of Sciences, Doctoral Cycle, University of Kinshasa, Kinshasa, Democratic Republic of \\ Congo \\ ${ }^{2}$ Faculty of Agricultural Sciences and Environment, Evangelical University in Africa, Bukavu, Democratic Republic of Congo \\ ${ }^{3}$ General Agronomy Section, High Institute of Agronomic and Veterinary Studies of Mushweshwe, Bukavu, Democratic Republic of Congo
}

\section{Email address:}

nsambumukonduasumu@gmail.com (N. M. Pascal), musibon.ergs@gmail.com (M. E. Dieudonné),

kanyinda2004@gmail.com (M. K. Jean-Noël)

${ }^{*}$ Corresponding author

\section{To cite this article:}

Nsambu Mukondwa Pascal, Musibono Eyul’Anki Dieudonné, Mputu Kanyinda Jean-Noël. Determination of the Level of Mercury Toxicity of Fish in Rivers Draining Gold Panning Sites in the Territory of Fizi, Eastern Democratic Republic of Congo. International Journal of Environmental Protection and Policy. Vol. 8, No. 1, 2020, pp. 1-10. doi: 10.11648/j.ijepp.20200801.11

Received: December 21, 2019; Accepted: December 30, 2019; Published: January 9, 2020

\begin{abstract}
The specimens of the studied fish were taken from the same sites along the rivers during 4 Campaigns (August 2016, December 2016, August 2017 and December 2017). This study specifically aims to evaluate the level of mercury toxicity in fish from these rivers based on their total mercury content and the ratio between the molar concentrations of total selenium and total mercury (TSe: $\mathrm{THg}$ ). Total selenium and total mercury were measured in fish by atomic absorption spectrophotometry (AAS). The molar concentrations of total mercury were determined by dividing the total mercury concentrations obtained for each fish by its molar mass of about $200.59 \mathrm{~g} \cdot \mathrm{mol}^{-1}$. Also, the total selenium molar concentrations were determined by dividing the total selenium contents obtained for each fish by its molar mass of order of 78.9 g.mol ${ }^{-1}$. In addition, the ratios between the molar concentrations of total selenium and total mercury (TSe: THg) were calculated from the quotient between the molar concentrations of total selenium and total mercury. The results found that all fish from the rivers of the Fizi gold panning sites studied had total mercury concentrations well above the fish quality standards $\left(0.5 \mathrm{mg} \cdot \mathrm{Kg}^{-1}\right)$. Silurus $s p$ fish had the highest total mercury levels compared to other fish, followed respectively by Haplochromis $s p$ and Oreochromis $s p$. However, it was found that all these species of fish studied do not pose a threat to human health because their molar concentrations of total selenium and total mercury (TSe: THg) are at least greater than 1. Oreochromis $s p$ had the highest ratios of TSe: THg molar concentrations to other fish successively followed by fish Haplochromis sp and Silurus sp. It would be necessary to train gold miners in the territory of Fizi about the proper management of gold washing effluents.
\end{abstract}

Keywords: Gold Panning, Sites, Total Mercury Content, Fish, Fizi Territory, East, Democratic Republic of Congo

\section{Introduction}

Fish have significant nutritional qualities that make them especially important foods. It has been proven that fishes are excellent sources of animal protein compared to meat [1]. They are also rich in minerals such as phosphorus and vitamins (A, D, E, and some of the B group). In addition, certain species of fish, in this case fatty fish are a source of omega 3, which are involved in the prevention of cardiovascular diseases, as well as in the development and functioning of the retina, the brain and the system nervous [2]. However, it should be noted that fish and other aquatic organisms may be contaminated by pollutants in the water such as mercury and other trace metals [3]. Some trace metal such as Zinc and copper are essential for the growth of aquatic organisms or to complete their life cycle, but become toxic when their absorption becomes excessive. On the other hand, other metals such as silver, cadmium, chromium, lead 
and mercury are rarely or never needed and are said to be toxic. Likewise, they are persistent pollutants that are not usually removed from the aquatic environment by natural processes, but tend to accumulate in sediments and aquatic organisms [4].

Mercury pollution of aquatic ecosystems as well as mercurial intoxication of fish and other marine organisms generally result from atmospheric deposition, discharges from gold washing effluents or non-recycled industrial effluents, etc. In recent times, mercury poisoning of fish remains a major problem in view of the increased deterioration of water quality in aquatic ecosystems due to discharges into the rivers of non-recycled effluents resulting from the industrial extraction of gold or gold panning $[4,5]$. At present, there is no information on the concentration of total mercury, nor data on the level of mercurial intoxication of fish in the rivers draining the gold panning sites in the Fizi territory, and yet the quality of these aquatic environments is said to be deteriorating as non-recycled gold panning effluents are discharged into them. In view of the above, it appears that fish in the rivers flowing through the gold panning sites in the Fizi territory would be exposed to the risk of mercurial intoxication without being taken into account. Given that, to date, there is no information related to the level of mercury exposure of fish in the rivers draining the gold panning sites in Fizi, this study specifically aims to evaluate the level of mercury toxicity of fish in the said rivers based on their total mercury levels and their ratios between the molar concentrations of total selenium and total mercury (TSe: THg).

\section{Material and Methods}

\subsection{Study Area}

Samples of the fish studied were fished in nine rivers (Kimbi, Mandje, Misisi, Kimuti, Kacumvi, Kuwa, Lubichako, Etó and Makungu) that drain the gold panning sites in the Fizi territory. This is one of eight territories in South Kivu province in the Democratic Republic of Congo. Geographically, the territory of Fizi is located between $3^{\circ} 30$ 'and $4^{\circ} 51^{\prime} 32$ " South latitude, $27^{\circ} 45^{\prime}$ 'and $29^{\circ} 14^{\prime} 10^{\prime \prime}$ longitude East. This territory administratively shares borders with the territory of Uvira in the North, the territory of Mwenga and Shabunda in the West, the territory of Kalemie (Tanganyika) in the South, and Lake Tanganyika in the East [6].

The information on the location of the points of sampling of water in these rivers is presented in Figure 1.

\subsection{Methods of Sampling and Analysis of Fish Samples}

The specimens of Silurus sp, Haplochromis sp and Oreochromis $s p$ studied were taken from the same sites along the Misisi, Etó, Kimbi, Kuwa, Makungu, Lubichako, Kacumvi, Kimuti and Mandje rivers during 4 seasons (August 2016, December 2016, August 2017 and December 2017). The choice of sampling sites for fish specimens was particularly based on the presence or absence of sources of pollution likely to affect the quality of the river waters of gold mining sites in the territory of Fizi. Samples of these specimens were taken at strategic sampling sites: upstream of the point of discharge (control or reference sites), immediately downstream of the site of release to assess the direct effect of pollutants, and downstream distant point of discharge to assess the extent of mercurial pollution caused by the release of mercurial effluents not recycled in the waterways of the mining area Fizi territory in particular. The fish studied were caught using a $500 \mu \mathrm{m}$ meshing mesh net with a circular opening $42 \mathrm{~cm}$ in diameter, mounted on a $131.88 \mathrm{~cm}$ long steel handle. During the sampling, net opening was placed against the current and the net was dragged slightly on the bottom along a transect $10 \mathrm{~m}$ long through the maximum possible habitats. The net was then raised and the contents poured into jars containing $10 \%$ formalin and stored at $4{ }^{\circ} \mathrm{C}$ in a cooler in the field. The sorting was done later in the laboratory. The area sampled was of the order of $10 \mathrm{~m} \times 0.42 \mathrm{~m}$, i.e $4.2 \mathrm{~m}^{2}$. The level of mercurial toxicity of the above-mentioned fish was evaluated via the total mercury content and the ratios between the molar concentrations of total selenium and the molar concentrations of total mercury (TSe: $\mathrm{THg}$ ).

Total mercury ( $\mathrm{THg}$ ) and total selenium (TSe) were assayed in said fish by atomic absorption spectrophotometry (AAS).

Thus, for the total mercury dosage, this method is based on the two-step analysis principle. The first step is to digest 0.5 $\mathrm{g}$ of the pulverized pulp from each fish species previously thawed at room temperature.

This digestion is carried out in the presence of acids (pure nitric acid concentrated at $65 \%$, pure sulfuric acid concentrated at $98 \%$, pure hydrochloric acid concentrated at $37 \%$ and hydroxylamine hydrochloride concentrated at $20 \%$ ) and potassium permanganate $\left(\mathrm{KMnO}_{4}\right)$ concentrated at $6 \%$. This step breaks down the organic matter and transforms the mercury into the $\mathrm{Hg}^{2+}$ form. Hydrochloric acid promotes the rapid decomposition of cinnabar $(\mathrm{HgS})$, resistant to the attack of nitric acid and sulfuric acid.

Potassium permanganate ensures complete oxidation of organic compounds refractory to acid decomposition. During this step, the manganese is reduced from the $\mathrm{Mn}^{7+}$ form to the $\mathrm{Mn}^{4+}$ form.

After digestion, a solution of hydroxylamine chloride $\left(\mathrm{NH}_{2} \mathrm{OH} . \mathrm{HCl}\right)$ reduces $\mathrm{MnO}_{2}$ and excess $\mathrm{KMnO}_{4}$ without reducing $\mathrm{Hg}^{2+}$.

During the second step, mercuric ions reduced to elemental mercury by a solution of stannous chloride $\left(\mathrm{SnCl}_{2}\right)$ concentrated at $10 \%$ are brought into a gas in a cell by bubbling air.

The mercury contained in the cell is assayed by the Atomic Absorption Spectrophotometer (AA500) at the wavelength of $253.7 \mathrm{~nm}$.

The total mercury (THg) concentration in this solution is deduced from the equation of the mercury calibration line. 


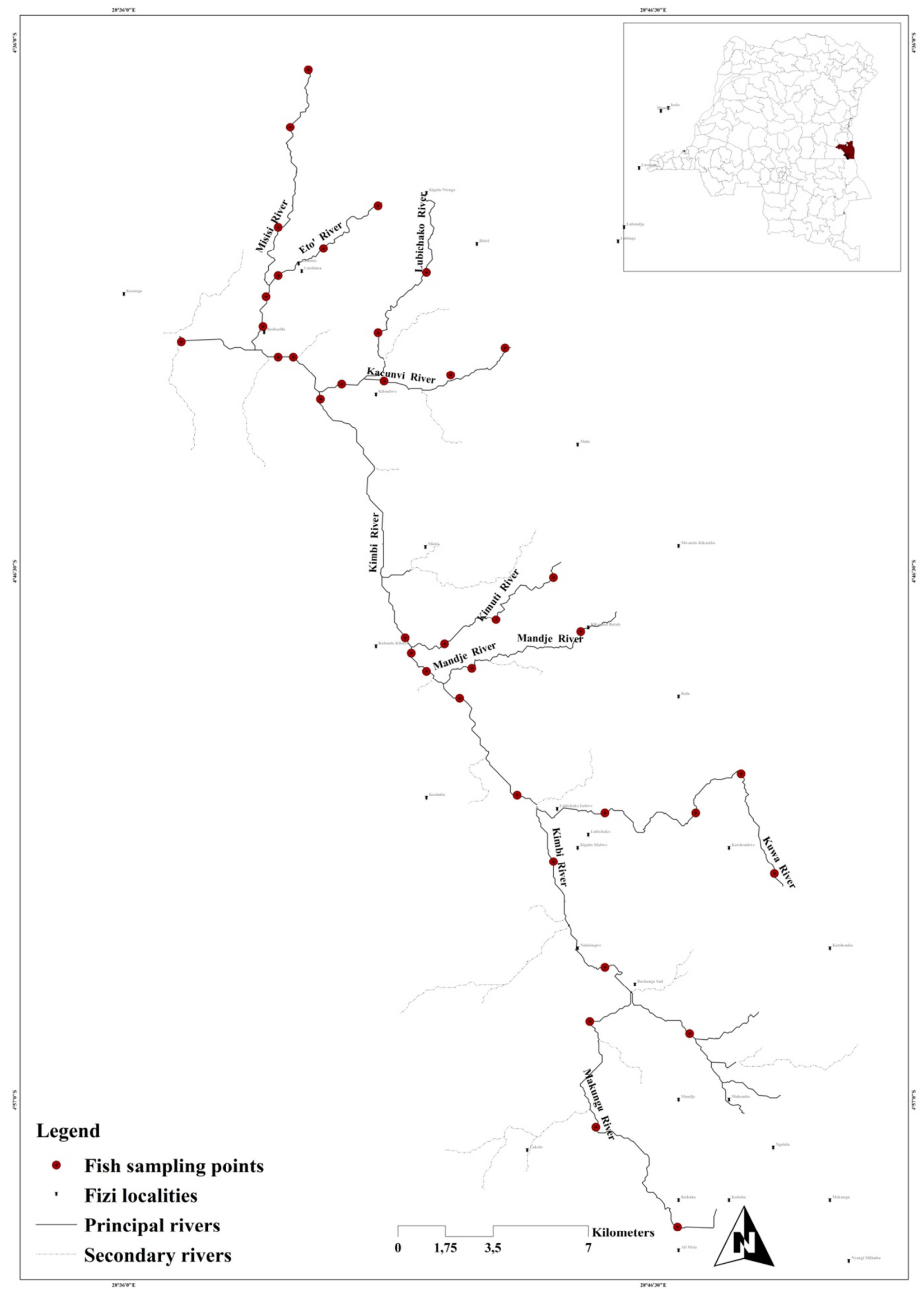

Figure 1. Location map of sampling sites of specimens of the studied fish. 
This calibration line consists of 6 standard points: standard 1 with a concentration of $0.1 \mu \mathrm{g} . \mathrm{L}^{-1}$; standard 2 of concentration $0.5 \mu \mathrm{g} . \mathrm{L}^{-1}$; standard 3 of concentration $1 \mu \mathrm{g} . \mathrm{L}^{-1}$; standard 4 of concentration $2 \mu \mathrm{g} . \mathrm{L}^{-1}$; standard 5 with a concentration of 4 $\mu \mathrm{g} . \mathrm{L}^{-1}$ and standard 6 with a concentration of $5 \mu \mathrm{g} . \mathrm{L}^{-1}$.

The levels of total mercury $(\mathrm{THg})$ in the fish samples are expressed in $\mathrm{mg} \cdot \mathrm{Kg}^{-1}$ according to the formula below:

$$
T H g\left(\frac{m g}{K g}\right)=\frac{[(\mathrm{AbsEch}-\mathrm{AbsB})-b]}{\text { a.PE. } 1000} \times \mathrm{Fd}
$$

With THg: final concentration of total mercury in fish samples (mg. $\mathrm{Kg}^{-1}$ ); AbsEch: absorbance of fish samples; AbsB: absorbance of the blank solution (control solution); a: slope $(\mathrm{Y}=\mathrm{a} \mathrm{X}+\mathrm{b})$; $\mathrm{b}$ : ordered at the origin; $\mathrm{Fd}$ : dilution factor, if necessary; PE: test portion in grams. Note: in order to validate the analysis, it must be ensured that the calibration line has a correlation coefficient whose square $r^{2}$ is greater than or equal to 0.98 [7].

With regard to the determination of total selenium, it should also be pointed out that the method of determination is based on the principle having two stages.

The principle of the method consists first of all in acid mineralization (wet mineralization) of $1 \mathrm{~g}$ of the ground material of each fish species previously defrosted at room temperature. During this mineralization, the selenium in the sample is reduced to the oxidation stage of +4 . Second, this selenium is converted to its volatile hydride by reacting the acidified sample with sodium borohydride $\left(\mathrm{NaBH}_{4}\right)$ concentrated at $4 \%$.

This volatile hydride is then entrained in a cell in which it oxidizes into elemental selenium in a heated atmosphere.

Finally, the selenium contained in the cell is assayed by atomic absorption spectrophotometry at the length of 196 $\mathrm{nm}$. The selenium concentration of the sample is determined from the regression equation obtained from the calibration line. This calibration line consists of 5 standard points: standard 1 of concentration $0 \mu \mathrm{g} . \mathrm{L}^{-1} ;$ standard 2 of concentration $5 \mu \mathrm{g} . \mathrm{L}^{-1}$; standard 3 of concentration $10 \mu \mathrm{g} . \mathrm{L}^{-1}$; standard 4 of concentration $15 \mu \mathrm{g} . \mathrm{L}^{-1}$ and standard 5 with a concentration of $25 \mu \mathrm{g} . \mathrm{L}^{-1}$.

The results are expressed in mg. $\mathrm{Kg}^{-1}$ of selenium in the sample, according to the following equation:

$$
\mathrm{TSe}(\mathrm{mg} / \mathrm{Kg})=\frac{\mathrm{A}}{1000} \times \mathrm{F}
$$

Where TSe: concentration of total selenium in the sample (mg. $\left.\mathrm{Kg}^{-1}\right)$; A: concentration of total selenium in the measured solution $\left(\mu \mathrm{g} . \mathrm{L}^{-1}\right) ; 1$ 000: conversion factor from $\mu \mathrm{g}$ to $\mathrm{mg} . \mathrm{L}^{-1} ; \mathrm{F}$ : dilution factor of the dosed solution, if necessary.

Note: in order to validate the analysis, it must be ensured that the calibration line has a correlation coefficient whose square $r^{2}$ is greater than or equal to 0.98 [8].

The molar concentrations of total mercury were determined by dividing the total mercury concentrations obtained for each fish by its molar mass equal to 200.59 g. $\mathrm{mol}^{-1}$. Also, the molar concentrations of total selenium were determined by dividing the total selenium concentrations obtained for each fish by its molar mass equal to 78.9 g. $\mathrm{mol}^{-1}$. In addition, the ratios between the molar concentrations of total selenium and total mercury (TSe: THg) were calculated from the quotient between the molar concentrations of total selenium and total mercury [7].

\subsection{Statistical Treatment of Data}

The data was encoded and processed using Microsoft Excel 2010. R version 2.15.1 software was used for descriptive data analysis while XLSTAT 2016 was used to separate the means of different factors at the level of significance of $5 \%$.

\section{Results and Discussion}

\subsection{Total Mercury Content in Various Species of Fish Studied}

\subsubsection{Total Mercury Content in Silurus sp Fish}

The results presented in Table 1 revealed that the average value of total mercury levels in Silurus $s p$ fish caught in rivers (Makungu, Misisi, Kuwa, Kimbi, Lubichako, Etó, Kimuti, Kacumvi and Mandje) from gold panning of the territory of Fizi was of the order of $3.371 \pm 0.215 \mathrm{mg} \cdot \mathrm{Kg}^{-1}$. However, the total mercury levels in Silurus sp fish that were caught in the above-mentioned rivers did not vary significantly according to the survey $(\mathrm{P}$-value $=0.682)$. However, these total mercury levels in said fish varied significantly from one river to another (Pvalue $=0.000)$. Specifically, Silurus sp fish caught in the Kimbi River showed the highest average total mercury content compared to Silurus $s p$ fish caught in other rivers $\left(8.279 \pm 1.057 \mathrm{mg} . \mathrm{Kg}^{-1}\right)$ alternately followed by Silurus $s p$ fish caught in the Misisi $\left(3.810 \pm 0.271 \mathrm{mg} . \mathrm{Kg}^{-1}\right)$ and Makungu (3.628 $\left.\pm 0.254 \mathrm{mg} . \mathrm{Kg}^{-1}\right)$ Rivers, whose mean values of total mercury levels are statistically identical; Etó $\quad\left(3.351 \pm 0.130 \quad \mathrm{mg} . \mathrm{Kg}^{-1}\right) ; \quad$ Lubichako (3.036 \pm 0.029 mg. $\left.\mathrm{Kg}^{-1}\right)$; Kacumvi (2.610 $\left.0.023 \quad \mathrm{mg} . \mathrm{Kg}^{-1}\right)$; Kuwa $\left(2.161 \pm 0.124 \mathrm{mg} . \mathrm{Kg}^{-1}\right)$; Mandje $\left(1.886 \pm 0.023 \mathrm{mg} . \mathrm{Kg}^{-1}\right)$; Kimuti (1.576 $\left.\pm 0.027 \mathrm{mg} . \mathrm{Kg}^{-1}\right)$.

Referring to the quality standards for fish products, it has been found that all Silurus $s p$ fish caught in various rivers in the gold panning areas of Fizi have total mercury levels well above the acceptable standards. For these standards, total mercury levels in fish may not exceed $0.5 \mathrm{mg} \cdot \mathrm{Kg}^{-1}$. Other researchers also found that total mercury levels in fish caught in the rivers Rio Negro, Yangtze, Ankobra and Tano draining gold panning sites Brazilian, Chinese and Ghanaian have varied very significantly along the rivers while exceeding the thresholds [9-11]. 
Table 1. Total mercury concentrations (THg) in the Silurus sp fish surveyed.

\begin{tabular}{|c|c|c|c|c|c|c|c|c|c|c|}
\hline $\begin{array}{l}\text { Sites / } \\
\text { Campaigns } \\
\text { and Parameter }\end{array}$ & Etó & Kacumvi & Kimbi & Kimuti & Kuwa & Lubichako & Makungu & Mandje & Misisi & Mean \\
\hline $\begin{array}{l}\text { THg in Silurus } \\
s p\left(\mathrm{mg} \mathrm{Kg}^{-1}\right)\end{array}$ & & P-value for th & he Campaigns & s: 0.682 & $P$-value for $t$ & the Rivers: 0.0 & & & & \\
\hline Campaign 1 & $3.203 \pm 0.122$ & $2.497 \pm 0.021$ & $7.916 \pm 0.864$ & $1.507 \pm 0.022$ & $2.066 \pm 0.121$ & $2.903 \pm 0.022$ & $3.470 \pm 0.237$ & $1.803 \pm 0.020$ & $3.638 \pm 0.263$ & $3.223 \pm 0.188$ \\
\hline Campaign 2 & $3.300 \pm 0.129$ & $2.570 \pm 0.022$ & $8.153 \pm 0.872$ & $1.553 \pm 0.024$ & $2.129 \pm 0.123$ & $2.989 \pm 0.025$ & $3.572 \pm 0.258$ & $1.858 \pm 0.021$ & $3.753 \pm 0.270$ & $3.320 \pm 0.194$ \\
\hline Campaign 3 & $3.399 \pm 0.132$ & $2.647 \pm 0.024$ & $8.397 \pm 0.932$ & $1.598 \pm 0.030$ & $2.193 \pm 0.125$ & $3.079 \pm 0.032$ & $3.680 \pm 0.260$ & $1.913 \pm 0.024$ & $3.866 \pm 0.274$ & $3.419 \pm 0.204$ \\
\hline Campaign 4 & $3.499 \pm 0.136$ & $2.725 \pm 0.026$ & $8.650 \pm 1.560$ & $1.646 \pm 0.032$ & $2.256 \pm 0.129$ & $3.172 \pm 0.036$ & $3.789 \pm 0.262$ & $1.972 \pm 0.028$ & $3.984 \pm 0.278$ & $3.521 \pm 0.276$ \\
\hline Mean & $3.351 \pm 0.130 \mathrm{cb}$ & $2.610 \pm 0.023 \mathrm{~d}$ & $8.279 \pm 1.057 \mathrm{a}$ & $1.576 \pm 0.027 \mathrm{~g}$ & $2.161 \pm 0.124 \mathrm{e}$ & $3.036 \pm 0.029 \mathrm{c}$ & $3.628 \pm 0.254 b$ & $1.886 \pm 0.023 \mathrm{f}$ & $3.810 \pm 0.271 \mathrm{~b}$ & $3.371 \pm 0.215$ \\
\hline
\end{tabular}

Averages with the same letters on the line or column are not statistically different at the significance level alpha $=0.05$; Campaign 1: August 2016; Campaign 2: December 2016; Campaign 3: August 2017; Campaign 4: December 2017; THg: Total mercury content.

\subsubsection{Total Mercury Levels in Fish Haplochromis sp}

The results highlighted in Table 2 revealed that the average value of total mercury levels in Haplochromis sp fish caught in the rivers (Makungu, Misisi, Kuwa, Kimbi, Lubichako, Etó, Kimuti, Kacumvi and Mandje) of the artisanal gold mining sites in the Fizi territory was equivalent to $3.036 \pm 0.175 \mathrm{mg} . \mathrm{Kg}^{-1}$. However, total mercury concentrations in Haplochromis sp fish caught in the above-mentioned rivers did not vary significantly according to the study Campaigns $(\mathrm{P}$-value $=0.714)$ while they varied highly significantly from one river to another $(\mathrm{P}$-value $=0.000)$. In particular, Haplochromis $s p$ fish caught in the Kimbi River had the highest mean total mercury content compared to Haplochromis $s p$ fish caught in other rivers $(7.455 \pm 0.317$ $\mathrm{mg} \cdot \mathrm{Kg}^{-1}$ ), followed alternately by Haplochromis $s p$ fish caught in the Misisi $\left(3.428 \pm 0.373 \mathrm{mg} \cdot \mathrm{Kg}^{-1}\right)$ and Makungu (3.294 $\left.\pm 0.374 \mathrm{mg} . \mathrm{Kg}^{-1}\right)$ Rivers whose mean values of total mercury concentrations are statistically similar; Etó (3.023 $\left.\pm 0.128 \mathrm{mg} . \mathrm{Kg}^{-1}\right)$; Lubichako (2.735 $\left.\pm 0.141 \mathrm{mg} \cdot \mathrm{Kg}^{-1}\right)$; Kacumvi $\left(2.338 \pm 0.083 \mathrm{mg} . \mathrm{Kg}^{-1}\right)$; then Kuwa $(1.933 \pm 0.025$ $\left.\mathrm{mg} \cdot \mathrm{Kg}^{-1}\right)$ and Mandje $\left(1.698 \pm 0.024\right.$ mg. $\left.\mathrm{Kg}^{-1}\right)$ with statistically similar mean values of total mercury concentrations; and finally Kimuti $\left(1.147 \pm 0.114 \mathrm{mg} \cdot \mathrm{Kg}^{-1}\right)$. Referring to the quality standards of fish products, it was found that all Haplochromis $s p$ fish caught in various rivers of the Fizi gold panning areas have total mercury contents considerably exceeding the standards according to which the acceptable values of total mercury contents in fish cannot exceed $0.5 \mathrm{mg} \cdot \mathrm{Kg}^{-1}$. These results are similar to those of other researchers who have also noted that total mercury concentrations in fish caught in the rivers of gold mining sites in the Brazilian Amazon region, Eastern Senegal and Tanzania varied very significantly between rivers while exceeding the limit thresholds [12-14].

Table 2. Concentrations of total mercury (THg) in fish Haplochromis sp studied.

\begin{tabular}{|c|c|c|c|c|c|c|c|c|c|c|}
\hline $\begin{array}{l}\text { Sites / } \\
\text { Campaigns and } \\
\text { Parameter }\end{array}$ & Etó & Kacumvi & Kimbi & Kimuti & Kuwa & Lubichako & Makungu & Mandje & Misisi & Mean \\
\hline $\begin{array}{l}\text { THg in } \\
\text { Haplochromis sp } \\
\left(\mathrm{mg} \mathrm{Kg}^{-1}\right)\end{array}$ & & P-value for th & the Campaigns & s: 0.692 & P-value for & the Rivers: $\mathbf{0 . 0}$ & & & & \\
\hline Campaign 1 & $2,890 \pm 0,047$ & $2,250 \pm 0,019$ & $7,128 \pm 0,300$ & $1,357 \pm 0,100$ & $1,848 \pm 0,017$ & $2,613 \pm 0,135$ & $3,123 \pm 0,368$ & $1,623 \pm 0,018$ & $3,278 \pm 0,364$ & $2,901 \pm 0,152$ \\
\hline Campaign 2 & $2,977 \pm 0,126$ & $2,316 \pm 0,029$ & $7,343 \pm 0,320$ & $1,396 \pm 0,110$ & $1,904 \pm 0,021$ & $2,693 \pm 0,140$ & $3,216 \pm 0,372$ & $1,673 \pm 0,022$ & $3,376 \pm 0,370$ & $2,988 \pm 0,168$ \\
\hline Campaign 3 & $3,067 \pm 0,129$ & $2,358 \pm 0,045$ & $7,561 \pm 0,322$ & $1,437 \pm 0,120$ & $1,960 \pm 0,027$ & $2,775 \pm 0,142$ & $3,367 \pm 0,375$ & $1,723 \pm 0,024$ & $3,478 \pm 0,378$ & $3,081 \pm 0,174$ \\
\hline Campaign 4 & $3,158 \pm 0,210$ & $2,429 \pm 0,239$ & $7,788 \pm 0,325$ & $1,480 \pm 0,125$ & $2,018 \pm 0,036$ & $2,857 \pm 0,147$ & $3,469 \pm 0,381$ & $1,773 \pm 0,030$ & $3,581 \pm 0,380$ & $3,173 \pm 0,208$ \\
\hline Mean & $3,023 \pm 0,128 \mathrm{cb}$ & $2,338 \pm 0,083 \mathrm{~d}$ & $17,455 \pm 0,317 \mathrm{a}$ & $1,417 \pm 0,114 \mathrm{f}$ & $1,933 \pm 0,025 \mathrm{e}$ & $2,735 \pm 0,141 \mathrm{c}$ & $3,294 \pm 0,374 b$ & $1,698 \pm 0,024 \mathrm{e}$ & $3,428 \pm 0,373 b$ & $3,036 \pm 0,175$ \\
\hline
\end{tabular}

Averages with the same letters on the line or column are not statistically different at the significance level alpha $=0.05$; Campaign 1: August 2016; Campaign 2: December 2016; Campaign 3: August 2017; Campaign 4: December 2017; THg: Total mercury content.

\subsubsection{Total Mercury Levels in Fish Oreochromis sp}

The results highlighted in Table 3 revealed that the mean value of total mercury levels in Oreochromis $s p$ fish caught in the rivers (Makungu, Misisi, Kuwa, Kimbi, Lubichako, Etó, Kimuti, Kacumvi and Mandje) of the gold panning sites in the Fizi territory was of the order of $2.462 \pm 0.178 \mathrm{mg} . \mathrm{Kg}^{-1}$. Nevertheless, the concentrations of total mercury in Oreochromis $s p$ fish that were caught in the above-mentioned rivers did not vary significantly according to the investigation Campaigns $(\mathrm{P}$-value $=0.714)$ even though they varied in a highly significant way from one river to another $(\mathrm{P}$-value $=$ 0.000 ). In particular, Oreochromis $s p$ fish caught in the
Kimbi River had the highest mean total mercury content compared to Oreochromis $s p$ fish caught in other rivers $\left(5.952 \pm 0.435 \mathrm{mg} \cdot \mathrm{Kg}^{-1}\right)$, followed successively by Oreochromis $s p$ fish caught in the Misisi $(2.747 \pm 0.174$ mg. $\left.\mathrm{Kg}^{-1}\right)$, Makungu $\left(2.619 \pm 0.203\right.$ mg. $\left.\mathrm{Kg}^{-1}\right)$ and Etó $\left(2.415 \pm 0.179 \mathrm{mg} \cdot \mathrm{Kg}^{-1}\right)$, whose mean values for total mercury concentrations are statistically similar; Lubichako (2.185 $\left.\pm 0.325 \mathrm{mg} \cdot \mathrm{Kg}^{-1}\right)$; Kacumvi (1.185 $\left.\pm 0.325 \mathrm{mg} \cdot \mathrm{Kg}^{-1}\right)$; followed by Kuwa River $\left(1.546 \pm 0.074 \mathrm{mg} \cdot \mathrm{Kg}^{-1}\right)$ and Mandje River $\left(1.363 \pm 0.075 \mathrm{mg} . \mathrm{Kg}^{-1}\right)$ with statistically equal mean values of total mercury concentrations; and Kimuti River $\left(1.139 \pm 0.072 \mathrm{mg} . \mathrm{Kg}^{-1}\right)$. Referring to the quality standards of 
fish products, it was found that all the Oreochromis $s p$ fish caught in various rivers in the Fizi gold panning areas have total mercury contents considerably exceeding the standards according to which the acceptable values of total mercury contents in fish cannot exceed $0.5 \mathrm{mg} \cdot \mathrm{Kg}^{-1}$. These observations agree with those of other researchers who also revealed that the concentrations of total mercury in fish caught in the rivers and reservoirs of the gold panning sites in Sfax (Tunisia) and in the semi-arid regions of Burkina Faso varied very significantly from one river to another while exceeding the limit thresholds $[5,15,16]$.

Table 3. Total mercury (THg) concentrations in Oreochromis sp fish studied.

\begin{tabular}{|c|c|c|c|c|c|c|c|c|c|c|}
\hline $\begin{array}{l}\text { Sites / } \\
\text { Campaigns and } \\
\text { Parameter }\end{array}$ & Etó & Kacumvi & Kimbi & Kimuti & Kuwa & Lubichako & Makungu & Mandje & Misisi & Mean \\
\hline $\begin{array}{l}\text { THg in } \\
\text { Oreochromis sp } \\
\left(\mathrm{mg.Kg}^{-1}\right)\end{array}$ & & P-value for th & e Campaigns: & 0.714 & P-value for & the Rivers: 0. & .000 & & & \\
\hline Campaign 1 & $2.310 \pm 0.012$ & $1.803 \pm 0.036$ & $5.701 \pm 0.027$ & $1.090 \pm 0.060$ & $1.478 \pm 0.070$ & $2.090 \pm 0.039$ & $2.503 \pm 0.014$ & $1.303 \pm 0.069$ & $2.628 \pm 0.010$ & $2.323 \pm 0.037$ \\
\hline Campaign 2 & $2.377 \pm 0.160$ & $1.856 \pm 0.040$ & $5.872 \pm 0.214$ & $1.122 \pm 0.063$ & $1.524 \pm 0.072$ & $2.153 \pm 0.410$ & $2.577 \pm 0.245$ & $1.343 \pm 0.074$ & $2.705 \pm 0.140$ & $2.392 \pm 0.158$ \\
\hline Campaign 3 & $2.450 \pm 0.253$ & $1.911 \pm 0.046$ & $6.048 \pm 0.236$ & $1.156 \pm 0.081$ & $1.569 \pm 0.075$ & $2.218 \pm 0.423$ & $2.657 \pm 0.257$ & $1.383 \pm 0.077$ & $2.786 \pm 0.250$ & $2.464 \pm 0.189$ \\
\hline Campaign 4 & $2.523 \pm 0.292$ & $1.967 \pm 0.123$ & $6.187 \pm 1.263$ & $1.189 \pm 0.083$ & $1.613 \pm 0.078$ & $2.278 \pm 0.427$ & $2.738 \pm 0.297$ & $1.423 \pm 0.080$ & $2.869 \pm 0.294$ & $2.671 \pm 0.326$ \\
\hline Mean & $2.415 \pm 0.179 b$ & $1.884 \pm 0.061 \mathrm{~d}$ & $5.952 \pm 0.435 \mathrm{a}$ & $1.139 \pm 0.072 \mathrm{f}$ & $1.546 \pm 0.074 \mathrm{e}$ & $2.185 \pm 0.325 c$ & $2.619 \pm 0.203 \mathrm{~b}$ & $1.363 \pm 0.075 \mathrm{e}$ & $2.747 \pm 0.174 b$ & $2.462 \pm 0.178$ \\
\hline
\end{tabular}

Averages with the same letters on the line or column are not statistically different at the significance level alpha $=0.05$; Campaign 1: August 2016; Campaign 2: December 2016; Campaign 3: August 2017; Campaign 4: December 2017; THg: Total mercury content.

\subsection{Total Selenium Levels in Different Species of Fish Studied}

\subsubsection{Total Selenium Levels (TSe) in Fish Silurus sp}

The results shown in Table 4 show that the mean value of total selenium levels in Silurus sp fish caught in the rivers studied was equivalent to $3.789 \pm 0.219 \mathrm{mg} . \mathrm{Kg}^{-1}$. However, total selenium concentrations in Silurus $s p$ fish that were caught in the rivers studied did not vary significantly across the surveys $(\mathrm{P}$-value $=0.623)$ although they did vary highly significantly from river to river $(\mathrm{P}$-value $=0.000)$. In particular, Silurus $s p$ fish caught in the Kimbi River had the highest mean value of total selenium content compared to Silurus $s p$ fish caught in other rivers $\left(8.697 \pm 0.340 \mathrm{mg} \cdot \mathrm{Kg}^{-1}\right)$, followed alternately by Silurus $s p$ fish caught in the Misisi (4.224 $\left.\pm 0.134 \mathrm{mg} . \mathrm{Kg}^{-1}\right)$ and Makungu (4.048 $\pm 0.424 \mathrm{mg} . \mathrm{Kg}$ $\left.{ }^{1}\right)$ Rivers whose mean values of total selenium concentrations are statistically similar; then Etó (3.770 $\left.\pm 0.354 \mathrm{mg} . \mathrm{Kg}^{-1}\right)$ and Lubichako (3.455 \pm 0.369 $\left.\mathrm{mg} \cdot \mathrm{Kg}^{-1}\right)$ whose mean values of total selenium concentrations are statistically identical; then Kacumvi $\left(3.030 \pm 0.155 \mathrm{mg} \cdot \mathrm{Kg}^{-1}\right)$; then Kuwa $\left(2.577 \pm 0.072 \mathrm{mg} \cdot \mathrm{Kg}^{-1}\right)$ and Mandje (2.306 $\left.\pm 0.057 \mathrm{mg} \cdot \mathrm{Kg}^{-1}\right)$ with statistically similar mean values of total selenium concentrations; and finally Kimuti $\left(1.994 \pm 0.044 \mathrm{mg} \cdot \mathrm{Kg}^{-1}\right)$. These findings are similar to those of other researchers who have shown also that total selenium concentrations in fish caught in streams and reservoirs of gold mining sites in the Brazilian Amazon, Malawi and Sfax (Tunisia) varied very significantly between rivers while exceeding the limit thresholds [17-19].

Table 4. Total selenium (TSe) concentrations in the Silurus sp fish studied.

\begin{tabular}{|c|c|c|c|c|c|c|c|c|c|c|}
\hline $\begin{array}{l}\text { Sites / } \\
\text { Campaigns and } \\
\text { Parameter }\end{array}$ & Etó & Kacumvi & Kimbi & Kimuti & Kuwa & Lubichako & Makungu & Mandje & Misisi & Mean \\
\hline $\begin{array}{l}\text { TSe in Silurus sp } \\
\left(\mathrm{mg}^{\left.-\mathrm{Kg}^{-1}\right)}\right.\end{array}$ & & \multicolumn{3}{|c|}{ P-value for the Campaigns: 0.623} & \multicolumn{6}{|c|}{ P-value for the Rivers: 0.000} \\
\hline Campaign 1 & $3.603 \pm 0.341$ & $2.897 \pm 0.138$ & $8.316 \pm 0.334$ & $1.907 \pm 0.014$ & $2.466 \pm 0.057$ & $3.303 \pm 0.324$ & $3.870 \pm 0.070$ & $2.203 \pm 0.050$ & $4.038 \pm 0.127$ & $3.623 \pm 0.162$ \\
\hline Campaign 2 & $3.713 \pm 0.352$ & $2.983 \pm 0.148$ & $8.565 \pm 0.340$ & $1.963 \pm 0.017$ & $2.539 \pm 0.064$ & $3.402 \pm 0.327$ & $3.986 \pm 0.536$ & $2.271 \pm 0.063$ & $4.160 \pm 0.129$ & $3.731 \pm 0.220$ \\
\hline Campaign 3 & $3.824 \pm 0.360$ & $3.073 \pm 0.163$ & $8.821 \pm 0.342$ & $2.023 \pm 0.023$ & $2.613 \pm 0.082$ & $3.504 \pm 0.410$ & $4.106 \pm 0.540$ & $2.339 \pm 0.067$ & $4.284 \pm 0.139$ & $3.843 \pm 0.236$ \\
\hline Campaign 4 & $3.940 \pm 0.364$ & $3.166 \pm 0.172$ & $9.086 \pm 0.345$ & $2.084 \pm 0.124$ & $2.691 \pm 0.087$ & $3.610 \pm 0.414$ & $4.230 \pm 0.548$ & $2.409 \pm 0.120$ & $4.413 \pm 0.143$ & $3.959 \pm 0.257$ \\
\hline Mean & $3.770 \pm 0.354 \mathrm{c}$ & $3.030 \pm 0.155 \mathrm{~d}$ & $8,697 \pm 0.340 \mathrm{a}$ & $1.994 \pm 0.044 \mathrm{f}$ & $2.577 \pm 0.072 \mathrm{e}$ & $3.455 \pm 0.369 c$ & $4.048 \pm 0.424 b$ & $2.306 \pm 0.075 \mathrm{e}$ & $4.224 \pm 0.134 b$ & $3.789 \pm 0.219$ \\
\hline
\end{tabular}

Averages with the same letters on the line or column are not statistically different at the significance level alpha =0.05; Campaign 1: August 2016; Campaign 2: December 2016; Campaign 3: August 2017; Campaign 4: December 2017; TSe: Total selenium content.

\subsubsection{Total Selenium Levels (TSe) in Fish Haplochromis sp}

The results contained in Table 5 showed that the mean value of total selenium levels in Haplochromis sp fish caught in the rivers studied was of the order of $3.450 \pm 0.097 \mathrm{mg} . \mathrm{Kg}$ 1. However, the concentrations of total selenium in Haplochromis $s p$ fish caught in the rivers studied did not vary significantly between study Campaigns (P-value =
0.622) although they did vary highly significantly from one river to another (P-value $=0.000)$. Specifically, Haplochromis $s p$ fish caught in the Kimbi River had the highest mean total selenium content compared to Haplochromis $s p$ fish caught in other rivers $(7.874 \pm 0.431$ mg. $\mathrm{Kg}^{-1}$ ), followed successively by Haplochromis $s p$ fish caught in the Misisi $\left(3.843 \pm 0.088 \mathrm{mg} . \mathrm{Kg}^{-1}\right)$ and Makungu (3.675 $\left.\pm 0.088 \mathrm{mg} . \mathrm{Kg}^{-1}\right)$ Rivers whose mean values of total 
selenium concentrations are statistically the same; then Etó (3.438 $\left.\pm 0.055 \mathrm{mg} . \mathrm{Kg}^{-1}\right)$; Lubichako (3.151 $\left.\pm 0.064 \mathrm{mg} . \mathrm{Kg}^{-1}\right)$; Kacumvi (2.77 $\left.\pm 0.051 \mathrm{mg} . \mathrm{Kg}^{-1}\right)$; then Kuwa $(2.352 \pm 0.029$ $\left.\mathrm{mg} . \mathrm{Kg}^{-1}\right)$ and Mandje $\left(2.114 \pm 0.031 \mathrm{mg} \cdot \mathrm{Kg}^{-1}\right)$ with statistically identical mean values of total selenium concentrations; and finally Kimuti $\left(1.827 \pm 0.032 \mathrm{mg} \cdot \mathrm{Kg}^{-1}\right)$.
Other researchers have also revealed that total selenium concentrations in fish caught in streams draining gold panning sites in Brazil, Yeji (Ghana) and Chad varied very significantly between rivers while exceeding threshold limits $[18,20,21]$.

Table 5. Total selenium (TSe) concentrations in the Haplochromis sp fish studied.

\begin{tabular}{|c|c|c|c|c|c|c|c|c|c|c|}
\hline $\begin{array}{l}\text { Sites / } \\
\text { Campaigns and } \\
\text { Parameter } \\
\end{array}$ & Etó & Kacumvi & Kimbi & Kimuti & Kuwa & Lubichako & Makungu & Mandje & Misisi & Mean \\
\hline $\begin{array}{l}\text { Tse in } \\
\text { Haplochromis } \\
\left.\text { sp (mg. Kg }{ }^{-1}\right) \\
\end{array}$ & & \multicolumn{3}{|c|}{ P-value for the Campaigns: 0.622} & \multicolumn{3}{|c|}{ P-value for the Rivers: 0.000} & & & \\
\hline Campaign 1 & $3.290 \pm 0.031$ & $2.650 \pm 0.030$ & $7.528 \pm 0.017$ & $1.757 \pm 0.027$ & $2.248 \pm 0.014$ & $3.013 \pm 0.059$ & $3.523 \pm 0.082$ & $2.023 \pm 0.016$ & $3.676 \pm 0.080$ & $3.301 \pm 0.040$ \\
\hline Campaign 2 & $3.386 \pm 0.042$ & $2.729 \pm 0.052$ & $7.753 \pm 0.058$ & $1.796 \pm 0.031$ & $2.316 \pm 0.018$ & $3.102 \pm 0.062$ & $3.628 \pm 0.084$ & $2.083 \pm 0.022$ & $3.786 \pm 0.086$ & $3.398 \pm 0.051$ \\
\hline Campaign 3 & $3.486 \pm 0.075$ & $2.812 \pm 0.060$ & $7.986 \pm 0.612$ & $1.849 \pm 0.034$ & $2.385 \pm 0.030$ & $3.196 \pm 0.065$ & $3.721 \pm 0.090$ & $2.143 \pm 0.035$ & $3.898 \pm 0.091$ & $3.497 \pm 0.121$ \\
\hline Campaign 4 & $3.592 \pm 0.073$ & $2.894 \pm 0.063$ & $8.227 \pm 1.036$ & $1.905 \pm 0.037$ & $2.458 \pm 0.054$ & $3.292 \pm 0.070$ & $3.830 \pm 0.097$ & $2.208 \pm 0.050$ & $4.014 \pm 0.093$ & $3.602 \pm 0.175$ \\
\hline Mean & $3.438 \pm 0.055 b c$ & $2.771 \pm 0.051 \mathrm{~d}$ & $7.874 \pm 0.431 \mathrm{a}$ & $1.827 \pm 0.032 \mathrm{f}$ & $2.352 \pm 0.029 \mathrm{e}$ & $3.151 \pm 0.064 \mathrm{c}$ & $3.675 \pm 0.088 b$ & $2.114 \pm 0.031 \mathrm{e}$ & $3.843 \pm 0.088 b$ & $3.450 \pm 0.097$ \\
\hline
\end{tabular}

Averages with the same letters on the line or column are not statistically different at the significance level alpha =0.05; Campaign 1: August 2016; Campaign 2: December 2016; Campaign 3: August 2017; Campaign 4: December 2017; TSe: Total selenium content.

\subsubsection{Total Selenium Levels (TSe) in Fish Oreochromis sp}

The results presented in Table 6 showed that the mean value of total selenium levels in Oreochromis sp fish caught in the rivers studied was $2.842 \pm 0.378 \mathrm{mg} \cdot \mathrm{Kg}^{-1}$. However, total selenium levels in Oreochromis sp fish caught in the Makungu, Kimbi, Misisi, Etó, Lubichako, Kacumvi, Kimuti, Mandje and Kuwa Rivers did not vary significantly between surveys $(\mathrm{P}$-value $=0.609)$, while they varied highly significantly between rivers (P-value $=0.000)$. Thus, Oreochromis $s p$ fish caught in the Kimbi River had the highest mean total selenium content compared to Oreochromis $s p$ fish caught in other rivers $(6.314 \pm 0.525$ $\left.\mathrm{mg} \cdot \mathrm{Kg}^{-1}\right)$, followed in turn by Oreochromis $s p$ fish caught in the Misisi $\left(3.168 \pm 0.656 \quad \mathrm{mg} . \mathrm{Kg}^{-1}\right)$ and Makungu
(3.049 $\left.\pm 0.664 \mathrm{mg} . \mathrm{Kg}^{-1}\right)$ Rivers whose mean values of total selenium concentrations are statistically the analogues; then Etó (2.836 $\left.\pm 0.650 \mathrm{mg} . \mathrm{Kg}^{-1}\right)$ and Lubichako (2.605 \pm 0.653 mg. $\mathrm{Kg}^{-1}$ ) whose mean values of total selenium concentrations are statistically identical; then Kacumvi (2.304 \pm 0.072 mg. $\left.\mathrm{Kg}^{-1}\right)$; then Kuwa $\left(1.964 \pm 0.084 \mathrm{mg} . \mathrm{Kg}^{-1}\right)$ and Mandje $\left(1.778 \pm 0.082 \mathrm{mg} . \mathrm{Kg}^{-1}\right)$ which have statistically similar mean values of total selenium concentrations; and finally Kimuti $\left(1.559 \pm 0.022 \mathrm{mg} \cdot \mathrm{Kg}^{-1}\right)$. Furthermore, other researchers have also revealed that total selenium concentrations in fish caught in streams draining gold mining sites in Moravia, Yeji (Ghana) and Tanzania varied very significantly between rivers while exceeding the threshold limits [2, 14, 21].

Table 6. Total selenium (TSe) concentrations in fish Oreochromis sp studied.

\begin{tabular}{|c|c|c|c|c|c|c|c|c|c|c|}
\hline $\begin{array}{l}\text { Sites / } \\
\text { Campaigns and } \\
\text { Parameter }\end{array}$ & Etó & Kacumvi & Kimbi & Kimuti & Kuwa & Lubichako & Makungu & Mandje & Misisi & Mean \\
\hline 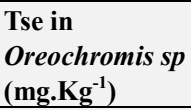 & & \multicolumn{3}{|c|}{ P-value for the Campaigns: 0.609} & \multicolumn{4}{|c|}{ P-value for the Rivers: 0.000} & & \\
\hline Campaign 1 & $2.710 \pm 0.625$ & $2.203 \pm 0.067$ & $6.068 \pm 0.015$ & $1.490 \pm 0.010$ & $1.878 \pm 0.078$ & $2.490 \pm 0.615$ & $2.903 \pm 0.653$ & $1.703 \pm 0.074$ & $3.028 \pm 0.647$ & $2.719 \pm 0.309$ \\
\hline Campaign 2 & $2.793 \pm 0.635$ & $2.270 \pm 0.070$ & $6.209 \pm 0.029$ & $1.534 \pm 0.014$ & $1.934 \pm 0.082$ & $2.564 \pm 0.625$ & $2.991 \pm 0.661$ & $1.752 \pm 0.080$ & $3.119 \pm 0.651$ & $2.796 \pm 0.316$ \\
\hline Campaign 3 & $2.877 \pm 0.665$ & $2.337 \pm 0.072$ & $6.394 \pm 1.025$ & $1.581 \pm 0.030$ & $1.992 \pm 0.087$ & $2.641 \pm 0.652$ & $3.105 \pm 0.670$ & $1.802 \pm 0.085$ & $3.214 \pm 0.658$ & $2.883 \pm 0.438$ \\
\hline Campaign 4 & $2.963 \pm 0.673$ & $2.408 \pm 0.077$ & $6.587 \pm 1.032$ & $1.630 \pm 0.032$ & $2.051 \pm 0.091$ & $2.725 \pm 0.720$ & $3.197 \pm 0.674$ & $1.854 \pm 0.089$ & $3.311 \pm 0.667$ & $2.970 \pm 0.451$ \\
\hline Mean & $2.836 \pm 0.650 \mathrm{c}$ & $2.304 \pm 0.072 \mathrm{~d}$ & $6.314 \pm 0.525 \mathrm{a}$ & $1.559 \pm 0.022 \mathrm{f}$ & $1.964 \pm 0.084 \mathrm{e}$ & $2.605 \pm 0.653 \mathrm{c}$ & $3.049 \pm 0.664 b$ & $1.778 \pm 0.082 \mathrm{e}$ & $3.168 \pm 0.656 b$ & $2.842 \pm 0.378$ \\
\hline
\end{tabular}

Averages with the same letters on the line or column are not statistically different at the significance level alpha =0.05; Campaign 1: August 2016; Campaign

2: December 2016; Campaign 3: August 2017; Campaign 4: December 2017; TSe: total selenium content.

\subsection{Relationships Between Molar Concentrations of Total Selenium and Total Mercury (TSe: THg) in Different Species of Fish Studied}

\subsubsection{Molar Concentration Ratios Between Total Selenium and Total (TSe: THg) for Fish Oreochromis sp}

Based on the results presented in Table 7, it appears that the molar concentration ratios between total selenium and total mercury (TSe: $\mathrm{THg}$ ) for Oreochromis $s p$ fish caught in the rivers draining the gold panning sites in the territory of Fizi was equal to $3.227 \pm 0.078$. However, the molar concentration ratios between total selenium and total mercury (TSe: $\mathrm{THg}$ ) in Oreochromis $s p$ fish caught in the Makungu, Kimbi, Misisi, Etó, Lubichako, Kacumvi, Kimuti, Mandje and Kuwa Rivers varied highly significantly from one river to another $(\mathrm{P}$-value $=0.000)$. For example, Oreochromis sp fish caught in the Kimuti River 
exhibited the molar concentration ratio (TSe: $\mathrm{THg}$ ) relatie to Oreochromis $s p$ fish caught in other rivers (3.649 \pm 0.108$)$ followed in turn by Oreochromis $s p$ fish caught in the Mandje (3.466 \pm 0.120$)$; Kuwa (3.388 \pm 0.041$)$ Rivers; Kacumvi (3.249 \pm 0.062$)$; Lubichako (3.172 \pm 0.088$)$; then Etó (3.124 \pm 0.024$)$, Makungu (3.089 \pm 0.052$)$ and Misisi (3.074 \pm 0.088$)$ whose molar concentration ratios between total selenium and total mercury (TSe: $\mathrm{THg}$ ) are statistically similar; and Kimbi $(2.834 \pm 0.122)$.

Furthermore, the molar concentration ratios between total selenium and total mercury in Oreochromis sp fish caught in the above rivers varied highly significantly from one survey to another (P-value $=0.000)$. By the way, the molar concentration ratio (TSe: $\mathrm{THg}$ ) for Oreochromis $s p$ fish was successively equal to $3.369 \pm 0.103$ in Campaign 4 (December 2017); 3.271 \pm 0.080 in Campaign 3 (August 2017); $3.181 \pm 0.077$ in Campaign 2 (December 2016) and $3.088 \pm 0.053$ in Campaign 1 (August 2016). These results are almost similar to those of other researchers who also found that the molar concentration ratios between total selenium and total mercury (TSe: $\mathrm{THg}$ ) in Oreochromis $s p$ fish caught in the streams of the gold panning sites were within acceptable norms while varying very significantly both by river and campaign $[13,22]$.

Table 7. Molar concentration ratios between total selenium and total mercury (TSe: THg) for fish Oreochromis sp studied.

\begin{tabular}{|c|c|c|c|c|c|c|c|c|c|c|}
\hline $\begin{array}{l}\text { Sites / } \\
\text { Campaigns and } \\
\text { Parameter }\end{array}$ & Etó & Kacumvi & Kimbi & Kimuti & Kuwa & Lubichako & Makungu & Mandje & Misisi & Mean \\
\hline $\begin{array}{l}\text { TSe: } \mathrm{THg} \text { in } \\
\text { Oreochromis sp }\end{array}$ & & P-value for $t$ & the Campaign & Is: 0.000 & $P$-value for $t$ & the Rivers: 0.0 & 000 & & & \\
\hline Campaign 1 & $2.987 \pm 0.020$ & $3.113 \pm 0.057$ & $2.709 \pm 0.116$ & $3.489 \pm 0.060$ & $3.239 \pm 0.037$ & $3.033 \pm 0.082$ & $2.954 \pm 0.008$ & $3.330 \pm 0.018$ & $2.939 \pm 0.081$ & $3.088 \pm 0.053 d$ \\
\hline Campaign 2 & $3.077 \pm 0.022$ & $3.207 \pm 0.060$ & $2.791 \pm 0.121$ & $3.594 \pm 0.120$ & $3.336 \pm 0.040$ & $3.124 \pm 0.088$ & $3.043 \pm 0.032$ & $3.430 \pm 0.122$ & $3.027 \pm 0.086$ & $3.181 \pm 0.077 \mathrm{c}$ \\
\hline Campaign 3 & $3.169 \pm 0.025$ & $3.289 \pm 0.064$ & $2.874 \pm 0.123$ & $3.702 \pm 0.124$ & $3.436 \pm 0.042$ & $3.217 \pm 0.091$ & $3.134 \pm 0.038$ & $3.499 \pm 0.126$ & $3.118 \pm 0.089$ & $3.271 \pm 0.080 \mathrm{~b}$ \\
\hline Campaign 4 & $3.264 \pm 0.028$ & $3.388 \pm 0.066$ & $2.961 \pm 0.128$ & $3.813 \pm 0.128$ & $3.540 \pm 0.044$ & $3.314 \pm 0.093$ & $3.228 \pm 0.129$ & $3.604 \pm 0.213$ & $3.212 \pm 0.096$ & $3.369 \pm 0.103 \mathrm{a}$ \\
\hline Mean & $3.124 \pm 0.024 f$ & $3.249 \pm 0.062 \mathrm{~d}$ & $2.834 \pm 0.122 \mathrm{~g}$ & $3.649 \pm 0.108 \mathrm{a}$ & $3.388 \pm 0.041 \mathrm{c}$ & $3.172 \pm 0.088 \mathrm{e}$ & $3.089 \pm 0.052 \mathrm{f}$ & $3.466 \pm 0.120 \mathrm{~b}$ & $3.074 \pm 0.088 \mathrm{f}$ & $3.227 \pm 0.078$ \\
\hline
\end{tabular}

Averages with the same letters on the line or column are not statistically different at the significance level alpha $=0.05$; Campaign 1: August 2016; Campaign 2: December 2016; Campaign 3: August 2017; Campaign 4: December 2017; TSe: THg =Molar concentration ratios between total selenium and total mercury.

\subsubsection{Molar Concentration Ratios Between Total Selenium and Total Mercury (TSe: THg) for Fish \\ Haplochromis sp}

Based on the results presented in Table 8, it was found that the ratios between the molar concentrations of total selenium and total mercury (TSe: THg) for Haplochromis $s p$ fish caught in the rivers of the artisanal gold mining sites in the Fizi territory was of the order of $3.117 \pm 0.357$. Nevertheless, the ratios between the molar concentrations of total selenium and total mercury (TSe: $\mathrm{THg}$ ) in Haplochromis sp fish caught in the Makungu, Kimbi, Misisi, Etó, Lubichako, Kacumvi, Kimuti, Mandje and Kuwa Rivers varied highly significantly from one river to another $(\mathrm{P}$-value $=0.000)$. For example, Haplochromis $s p$ fish caught in the Kimuti River showed values for the molar ratios of total selenium to total mercury (SeT: $\mathrm{HgT}$ ) relative to Haplochromis $s p$ fish caught in other rivers (3.453 \pm 0.763$)$, followed alternately by Haplochromis $s p$ fish caught in the Mandje River (3.320 \pm 0.862$)$; Kuwa (3.240 \pm 0.687$)$; Kacumvi (3.136 \pm 0.654$)$; Lubichako (3.069 \pm 0.084$)$; then Etó (3.031 \pm 0.043$)$, Makungu $(3.006 \pm 0.061)$ and Misisi
$(2.989 \pm 0.036)$ whose values of the ratios of molar concentrations of total selenium and total mercury (TSe: THg) are statistically identical; and Kimbi $(2.811 \pm 0.027)$.

Similarly, the ratios between the molar concentrations of total selenium and total mercury in Haplochromis $s p$ fish caught in the above-mentioned rivers varied highly significantly from one investigation Campaign to another (Pvalue $=0.000)$. In fact, the ratio between the molar concentrations of total selenium and total mercury (TSe: $\mathrm{THg}$ ) for Haplochromis $s p$ fish was respectively equal to $3.257 \pm 0.373$ in Campaign 4 (December 2017); 3.162 \pm 0.370 in Campaign 3 (August 2017); 3.070 \pm 0.358 in Campaign 2 (December 2016) and 2.980 \pm 0.329 in Campaign 1 (August 2016). These findings are similar to those of other researchers who also noted that the ratios between the molar concentrations of total selenium and total mercury (TSe: $\mathrm{THg}$ ) for Haplochromis sp fish caught in the streams of the gold panning sites were within acceptable norms while varying very significantly depending on the rivers and the investigation campaigns [13, 21, 23].

Table 8. Molar concentration ratios between total selenium and total mercury (TSe: THg) for fish Haplochromis sp studied.

\begin{tabular}{|c|c|c|c|c|c|c|c|c|c|c|}
\hline $\begin{array}{l}\text { Sites / } \\
\text { Campaigns } \\
\text { and } \\
\text { Parameter }\end{array}$ & Etó & Kacumvi & Kimbi & Kimuti & Kuwa & Lubichako & Makungu & Mandje & Misisi & Mean \\
\hline $\begin{array}{l}\text { TSe: THg in } \\
\text { Haplochromis } \\
\text { sp }\end{array}$ & & P-value for th & he Campaigns & s: 0.000 & $P$-value for $t$ & he Rivers: 0.0 & & & & \\
\hline Campaign 1 & $2.898 \pm 0.012$ & $3.000 \pm 0.561$ & $2.687 \pm 0.020$ & $3.301 \pm 0.745$ & $3.098 \pm 0.679$ & $2.935 \pm 0.026$ & $2.872 \pm 0.050$ & $3.174 \pm 0.840$ & $2.858 \pm 0.027$ & $2.980 \pm 0.329 \mathrm{~d}$ \\
\hline Campaign 2 & $2.985 \pm 0.046$ & $3.090 \pm 0.651$ & $2.768 \pm 0.024$ & $3.400 \pm 0.760$ & $3.191 \pm 0.685$ & $3.023 \pm 0.100$ & $2.958 \pm 0.060$ & $3.269 \pm 0.865$ & $2.944 \pm 0.032$ & $3.070 \pm 0.358 \mathrm{c}$ \\
\hline
\end{tabular}




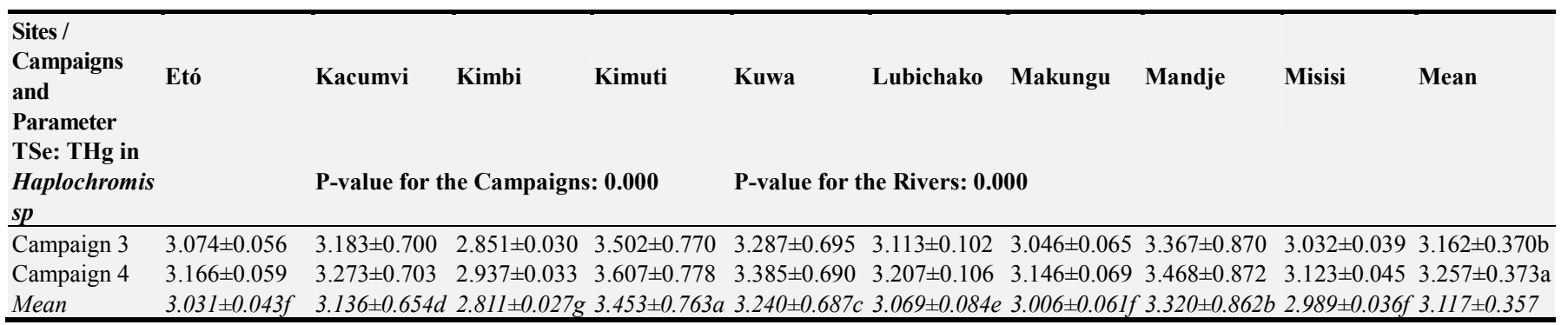

Averages with the same letters on the line or column are not statistically different at the significance level alpha =0.05; Campaign 1: August 2016; campaign 2: December 2016; Campaign 3: August 2017; Campaign 4: December 2017; TSe: THg $=$ Molar concentration ratios between total selenium and total mercury.

\subsubsection{Molar Concentration Ratios Between Total Selenium and Total Mercury (TSe: THg) for Fish Silurus sp}

The results presented in Table 9 revealed that the ratios between the molar concentrations of total selenium and total mercury (TSe: THg) for Silurus sp fish caught in the rivers of the artisanal gold mining sites in Fizi territory were equivalent to $3.053 \pm 0.286$. However, the ratios between the molar concentrations of total selenium and total mercury (TSe: THg) in Silurus sp fish caught in the Makungu, Kimbi, Misisi, Etó, Lubichako, Kacumvi, Kimuti, Mandje and Kuwa Rivers varied highly significantly from one river to another (P-value $=0.000)$. For example, Silurus $s p$ fish caught in the Kimuti River had the highest molar ratios of total selenium to total mercury compared to Silurus $s p$ fish caught in other rivers $(3,374 \pm 0.478)$ followed successively by Silurus $s p$ fish caught in the Mandje (3.252 \pm 0.344$)$ and Kuwa (3.180 \pm 0.361$)$ Rivers with molar ratios of total selenium and total mercury (TSe: $\mathrm{THg}$ ) are statistically similar; then Kacumvi (3.090 \pm 0.257$)$; Lubichako (3.028 \pm 0.208$)$; Etó (3.008 \pm 0.231$)$; finally Makungu (2.963 \pm 0.219$)$, Misisi
$(2.796 \pm 0.236)$ and Kimbi $(2.786 \pm 0.246)$ whose molar ratios of total selenium and total mercury (TSe: $\mathrm{THg}$ ) are statistically the same.

The ratios between the molar concentrations of total selenium and total mercury in Silurus sp fish caught in the above-mentioned rivers also varied highly significantly from one investigation Campaign to another $(\mathrm{P}$-value $=0.000)$. In fact, the ratios between the molar concentrations of total selenium and total mercury in Silurus sp fish were respectively equal to $3.192 \pm 0.297$ in Campaign 4 (December 2017); 3.099 \pm 0.288 in Campaign 3 (August 2017); $3.004 \pm 0.283$ in Campaign 2 (December 2016) and $2.917 \pm 0.278$ in Campaign 1 (August 2016). These observations are consistent with those of other researchers which also revealed that the ratios between the molar concentrations of total selenium and total mercury (TSe: $\mathrm{THg}$ ) in Silurus sp fish caught in rivers draining gold panning sites were within acceptable norms, although they varied very significantly in both rivers and survey Campaigns [13, $21,22,24]$.

Table 9. Molar concentration ratios between total selenium and total mercury (TSe: T Hg) for fish Silurus sp.

\begin{tabular}{|c|c|c|c|c|c|c|c|c|c|}
\hline $\begin{array}{l}\text { Sites / } \\
\text { Campaigns and } \\
\text { Parameter } \\
\end{array}$ & Etó & Kacumvi & Kimbi & Kimuti & Lubichako & Makungu & Mandje & Misisi & Mean \\
\hline $\begin{array}{l}\text { TSe: THg in } \\
\text { Silurus sp } \\
\end{array}$ & & P-value for $t$ & the Campaigr & ns: 0.000 & P-value for the Rivers: 0.0 & & & & \\
\hline Campaign 1 & $2.863 \pm 0.223$ & $2.954 \pm 0.250$ & $2.663 \pm 0.230$ & $3.225 \pm 0.474$ & $3.041 \pm 0.3572 .895 \pm 0.200$ & $2.829 \pm 0.211$ & $3.109 \pm 0.332$ & $2.673 \pm 0.225$ & $2.917 \pm 0.278 \mathrm{~d}$ \\
\hline Campaign 2 & $2.949 \pm 0.230$ & $3.043 \pm 0.254$ & $2.743 \pm 0.236$ & $3.322 \pm 0.476$ & $3.132 \pm 0.3602 .982 \pm 0.206$ & $2.913 \pm 0.215$ & $3.203 \pm 0.341$ & $2.753 \pm 0.230$ & $3.004 \pm 0.283 c$ \\
\hline Campaign 3 & $3.064 \pm 0.234$ & $3.134 \pm 0.260$ & $2.826 \pm 0.245$ & $3.422 \pm 0.480$ & $3.226 \pm 0.362 \quad 3.071 \pm 0.210$ & $3.011 \pm 0.218$ & $3.299 \pm 0.350$ & $2.836 \pm 0.235$ & $3.099 \pm 0.288 b$ \\
\hline Campaign 4 & $3.156 \pm 0.236$ & $3.228 \pm 0.263$ & $2.91 \pm 0.272$ & $3.525 \pm 0.483$ & $3.322 \pm 0.364 \quad 3.164 \pm 0.214$ & $3.101 \pm 0.231$ & $3.398 \pm 0.352$ & $2.921 \pm 0.254$ & $3.192 \pm 0.297 \mathrm{a}$ \\
\hline Mean & $3.008 \pm 0.231 \mathrm{~d}$ & $3.090 \pm 0.257 \mathrm{c}$ & $2.786 \pm 0.246 \mathrm{e}$ & $3.374 \pm 0.478 \mathrm{a}$ & $3.180 \pm 0.361 \mathrm{~b} 3.028 \pm 0.208 \mathrm{~cd}$ & $2.963 \pm 0.219 \mathrm{e}$ & $3.252 \pm 0.344 \mathrm{~b}$ & $2.796 \pm 0.236 \mathrm{e}$ & $3.053 \pm 0.286$ \\
\hline
\end{tabular}

Averages with the same letters on the line or column are not statistically different at the significance level alpha =0.05; Campaign 1: August 2016; Campaign 2: December 2016; Campaign 3: August 2017; Campaign 4: December 2017; TSe: THg $=$ Molar concentration ratios between total selenium and total mercury.

\section{Conclusion}

This research showed that all fish caught in various rivers draining the gold panning sites of Fizi had total mercury levels that significantly exceeded the fish resource quality standards, which stipulate that acceptable levels of total mercury in fish may not exceed $0.5 \mathrm{mg} \cdot \mathrm{Kg}^{-1}$. In addition to this, Silurus $s p$ fish had the highest total mercury levels compared to other fish followed by Haplochromis $s p$ and
Oreochromis $s p$ fish respectively. However, not all of these fish species studied were found to pose a threat to human health because their molar ratios of total selenium and total mercury (TSe: THg) are at least greater than 1. In such circumstances, the antagonistic effect between mercury and selenium occurs, in that selenium protects aquatic organisms from mercury toxicity. In addition to this, Oreochromis $s p$ fish had the highest molar ratios of total selenium and total mercury (TSe: THg) in relation to other fish, followed successively by Haplochromis sp and Silurus sp fish. In view 
of the above, it is necessary to combat mercury pollution of aquatic ecosystems in gold mining sites in the territory of in order to preserve both the health of aquatic organisms and the health of consumers of the above-mentioned fishery products. It would be important to train gold miners in the Fizi territory in the proper management of gold mining effluents, the promotion of modern artisanal gold mining techniques that significantly reduce environmental pollution, etc.

\section{Acknowledgements}

We sincerely thank the gold miners, the gold traders and the inhabitants of the gold mining sites in the Fizi territory; $\mathrm{Mr}$ Nakalonge André and Mr Mwimangire Cephas for lending us a strong hand during the completion of this research.

\section{References}

[1] Cresson, P., Bouchoucha, M., F. Mirallesand R. Elleboode, Are red mullet efficient as bio-indicators of mercury contamination? A case study from the French Mediterranean. Marine Pollution Bulletin. 2015. 91: p. 191-199.

[2] Houserova, P., Kuban, V., P. Spurny andP. Habarta, Determination of total mercury and mercury species in fish and aquatic ecosystems of Moravian rivers. Veterinarni Medicina. 2006.51 (3): p. 101-110.

[3] Hardisson, A., C. Rubio and A. Gutierrez, Total mercury in aquaculture fish. Pol. J. Environ. Stud. 2012. 21 (5): p. 1203-1209.

[4] N. Marusczak, Etude $d u$ transfert du mercure et $d u$ méthylmercure dans les écosystèmes lacustres alpins. Thèse de doctorat en Sciences de l'environnement, Université de Grenoble, France, 2010.

[5] David, C., Neil, M., Robin, A., Randy, B., Satyendra, P., A. Jennifer andJ. Kevin, An overview of mercury concentrations in freshwater fish species: a national fish mercury dataset for Canada. Can. J. Fish. Aquat. Sci. 2013. 70: p. 1-16.

[6] W. Munyaas, Un civil dans la guerre en RDC, l'errance d'un réfugié congolais. Ed Harmattan, Paris, 2006.

[7] M. A. H, Détermination $d u$ mercure: méthode par spectrophotométrie d'absorption atomique, formation de vapeur. Centre d'expertise en analyse environnementale du Québec, 2006.

[8] A. Boumehres, Etude comparative des techniques d'extraction des éléments traces métalliques dans le foie, le rein et le lait et leur détermination par spectrométrie d'absorption atomique (flamme et four graphite). Mémoire de Magister en médecine vétérinaire, Université de Toulouse, Paris, 2010.

[9] Schneider, L., Belger, L., J. Burger and R. Vogt, Mercury bioaccumulation in four tissues of Podocnemis erythrocephala (Podocnemididae: Testudines) as a function of water parameters. The Science of the Total Environment. 2009. 407 (3): p. 1048-1054.

[10] Yi, Y., Z. Yang and S. Zhang, Ecological risk assessment of heavy metals in sediment and human health risk assessment of heavy metals in fishes in the middle and lower reaches of the Yangtze River basin. Environmental Pollution. 2011. 159: p. 2575-2585.

[11] K. Noahand A. Anthony, Influence of mining related activities on levels of mercury in water, sediment and fish from the Ankobra and Tano River basins in South Western Ghana. Environ Syst Res. 2016. 5: p. 10-17.

[12] Schneider, L., Belger, L., Burger, J., R. Vogt and C. Ferrara, Mercury Levels in Muscle of Six Species of Turtles Eaten by People Along the Rio Negro of the Amazon Basin. Archives of Environmental Contamination and Toxicology. 2010. 58 (2): p. 444-450.

[13] B. Niane, Impacts environnementaux liés à l'utilisation du mercure lors de l'exploitation artisanale de l'or dans la région de Kédougou (Sénégal oriental). Thèse de doctorat en Sciences de la Terre, Université de Genève, Genève, 2014.

[14] Campbell, L., Verburg, P., P. Dixon and R. Hecky, Mercury biomagnification in the food web of Lake Tanganyika (Tanzania, East Africa). Science of the Total Environment. 2008. 402: p. 184-191.

[15] Ouédraogo and Aymot, Mercury, arsenic and selenium concentrations in water and fish from sub-Saharan semi-arid freshwater reservoirs (Burkina Faso). Science of the Total Environment. 2013. 444: p. 243-254.

[16] Mezghani-Chaari, S., A. Hamza and A. Hamza-Chaffai, Mercury contamination in human hair and some marine species from Sfax coasts of Tunisia: levels and risk assessment. Environmental Monitoring and Assessment. 2011. 180: p. $477-487$.

[17] Natália, F., Gilson, A., Katharina, E., A. João and C. Marta, Benthic fish blood as a biomarker for recent exposure to mercury. Limnetica. 2018.37 (1): p. 129-143.

[18] Kidd, K., Bootsma, H., Hesslein, R., L. Lyle and R. Mecky, Mercury Concentrations in the Food Web of Lake Malawi, East Africa. Journal of Great Lakes Research. 2013. 2: p. 258-266.

[19] Kidd, K., G. Stern and J. Lemoalle, Mercury and Other Contaminants in Fish from Lake Chad, Africa. Bulletin of Environmental Contamination and Toxicology. 2014. 73: p. 249-256.

[20] F. Hans, Mercury in boreal freshwater fish-factors and processes governing increasing concentrations. $\mathrm{PhD}$ dissertation in Environmental Sciences, University of Oslo, Suisse, 2015.

[21] Kwaansa, Agorku, andNriagu, Levels of Total Mercury in Different Fish Species and Sediments from the Upper Volta at Yeji in Ghana. Bulletin of Environmental Contamination and Toxicology. 2011. 86: p. 406-409.

[22] J. Burger and M. Gochfeld, Selenium and mercury molar ratios in saltwater fish from New Jersey: individual and species variability complicate use in human health fish consumption advisories. Envirn Res. 2012. 114: p. 12-23.

[23] Kouamé, M., Godi, H., A. Yolande and A. N'Zi, Estimation de l'apport en mercure à partir de la consommation de poisson en Côte d'Ivoire. Sciences \& Nature. 2007. 4 (2): p. 171-177.

[24] Rym, E., L. Chouba et M. Kraiem., Evaluation de la contamination chimique par les métaux traces $(\mathrm{Cd}, \mathrm{Pb}, \mathrm{Hg}$ et $\mathrm{Zn}$ ) du zooplancton et de la sardinelle (Sardinella aurita) dans le golfe de Tunis. Bull. Inst. Natn. Scien. Tech. Mer de Salammbô. 2008. 35: p. 87-94. 